\title{
THE DEVELOPMENT OF ECOTOURISM-BASED FISHERMEN HOUSING ON PANNIKIANG ISLAND
}

\author{
Mimi Arifin*, Andi Evi Tri Lestari** \\ *) Lecturer of Urban and Regional Planning Study Program, Faculty of \\ Engineering, Hasanuddin University \\ **) Student of Urban and Regional Planning Study Program, Faculty of \\ Engineering, Hasanuddin University \\ Email:mimiarifin@yahoo.com, andievi94@gmail.com
}

\begin{abstract}
Pannikiang Island is an ecotourism area developed by the government of Barru Regency. The existence of ecotourism is expected to bring positive influence to the local community, especially to the local fishermen's housings. Nevertheless, the housing quality and the welfare of local community are as yet weak. This reserach aims to analyze the proper and integrated development directives with environmental potential. The method used in the research is descriptive method by applying qualitative, quantitative, comparative and spasial analysis. Based on the analysis, the development directives of ecotourism-based housing on Pannikiang Island is semi-intensive tourism activities that give the knowledge as well as the education for tourists, fishermen's housings is developed as an support accommodation to ecotourism activity and having double function as a homestay and a place where processed marine and mangrove are marketed, enhancing the quality of the ecotourism facilities and infrastructure and furthermore, the development of ecotourism based on community participation.
\end{abstract}

Keywords: Development Directive, Fishermen Housing, Ecotourism, Pannikiang Island

\section{INTRODUCTION}

Generally, coastal settlement in Indonesia has some problems especially in the level of prosperity and environmental quality. One of the causes is the lack of facilities and infrastructure in the sector of marine and fishery. Meanwhile, low environmental quality in coastal settlement areas is due to the lack of basic infrastructure availability and facility that impact on poor productivity (Walhi, 2008 in Nugrahanti 2015).

Pannikiang is one of islands located in Balusu Sub-District of Barru Regency with an area of 94.5 hectares. Pannikiang Island is also inhabited by 103 people with livelihoods as fishermen (The Population Data of Madello Village, October 2016) and It is covered by 30 species of mangrove. The area of mangrove 
reaches 86.31 hectares or $91 \%$ of the land that makes Pannikiang Island has ecotourism potential (Tourism Potential Data of Barru Regency, 2016). Hence, Barru Regency has launched out the island as tourist area by providing mangrove track used to relish mangrove area

Based on Spatial Plans of Barru Regency in 2011-2031, some areas of Balusu Sub-District are designated as rural settlement areas as well as a protected area (a nature reserve, nature preservation and cultural reserve areas) especially a mangrove forest area (see Figure 1). Unfortunately, the island has very minimal supporting facilities and infrastructure, the resident of Pannikiang Island has not optimized the potential as well. Consequently, the area is still not exposed yet. While, It was set by a tourism regulation in law of Indonesian Republic No. 19 of 2009 that tourism area should has tourist attraction, public facilities, tourism facilities, accessibility, along with interconnected community and completes the realization of tourism.

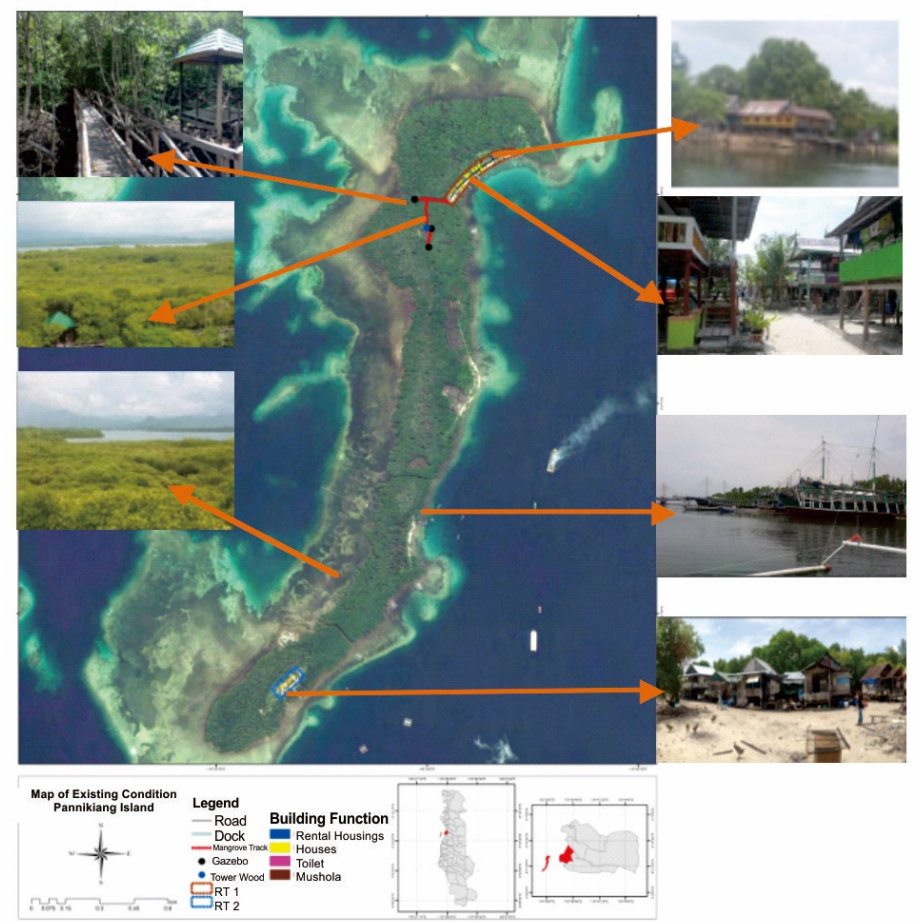

Figure 1. Existing Condition

The existence of nature tourism activities in Pannikiang Island is expected to support the fulfillment of community regarding economic needs. Therefore, it is necessary to do development so that tourism activities carried out wherever possible does not cause damage, in other words, structuring effort carried out is to manage the potential of ecotourism so that the prosperity of the community can be improved and implemented in a sustainable manner. Thus this research expected to provide development directives recommendations to the regional government to develop this area as one of the main tourist area in Barru regency. 


\section{THEORY}

\section{Settlement}

According to Law No. 01 of 2011, housing and settlement area are a unified system consisting of coaching, housing administration, settlement area administration, maintenance and repair, prevention and quality improvement to slum housing and settlement, land provision, funding and financing system, and also community roles.

1. Housing and Settlement of Coastal Community

a. Coastal Building Form

1) The stilt house form is generally located on the areas above water, both on the coastal border space and land areas.

2) Regular house form is generally located on puddle-free areas.

b. Ownership Status of Building Land in Coastal Area

1) State Land Status on water or land.

2) Land ownership for generations.

3) Building house pattern in a family group.

4) Land tenure by traditional coastal reclamation.

c. Requirements for the development of coastal housing and settlement (Wunas, S in Purnamasari, 2015) are:

1) Distance between buildings that considers every house to obtain lighting and a good air circulation, away from infectious diseases, and easy implementation of environmental infrastructure provision.

2) Distance between building and road that can support smooth and safety traffic, reduce dirty air and noise pollutions, and availability of playground.

3) Distance between building and coast that can maintain coastal sustainability, can be filled with green paths to reduce wind power, and overcome coastal erosion.

4) Availability of basic infrastructure that can support the life quality of the residents.

\section{Ecotourism}

Ecotourism is defined as a concept of sustainable tourism development aimed at supporting environmental (natural and cultural) conservation efforts and increasing community participation in management, thus it provides economic benefits to local community. According to Tuwo (2011), the objectives of ecotourism are (1) to realize responsible tourism operations which support efforts in natural environment conservation, historical, and cultural heritage; (2) to increase community participation and to provide economic benefits to local community; (3) To be a model for other tourism development through ecotourism principles application.

According to Tuwo (2011:32), ecotourism has three criteria which are to provide conservation value that can be calculated, involving the community, and profitable and can maintain by itself. These three criteria can be met when every ecotourism activity combines four components: ecosystem, community, culture, and economy. According to the Ministry of Culture and Tourism of the Republic of 
Indonesia (2009) in Waluya and Jamil (2016), ecotourism has many definitions entirely principle in tourism whose activities refer to 5 (five) important elements:

1. Provide experience and education for tourists to enhance understanding and appreciation of the tourist destination that they visited. Education is provided through an understanding of the importance of environmental conservation while experience is provided through creative tourism activities accompanied by excellent service;

2. Minimize negative impacts that could damage environmental and cultural characteristics of the area visited;

3. Involve the community in the management and implementation;

4. Provide economic benefits, especially to local community. Therefore, ecotourism activities must be profitable;

\section{METHODS}

\section{Data Collection Techniques}

The data collection techniques used in this research are:

1. Primary Data

Through this method, researcher directly recorded data found in housing land, area potency and accessibility condition, and ecotourism supporting infrastructure in research area.

2. Secondary Data

In this research, secondary data in the form of literature, books, journals, theses, documents, and previous research related to this research. These data can be obtained from related institutions and literature study.

\section{Population and Samples}

a. Population

This research used all existing houses in Pannikiang island, in this case including Pannikiang Island,Madello village, Balusu sub-district, Barru.

b. Samples

In this research, saturation sampling is used. Saturation sampling is a sample determining technique if all members of population are used as a sample (Sugiyono, 2012:96). It is conducted because the population is relatively small which is 34 samples and reserach aims to make generalizations with a very small error.

\section{Analysis Techniques}

Data analysis technique in this research was done by the following methods:

1. Qualitative Descriptive Analysis

The qualitative descriptive analysis was descriptive narrative that is used to describe descriptively existing condition in the field. The analysis was used to 
answer the second formulation of problem regarding the natural and socionatural potential and to answer the third formulation of problem regarding the development directives.

2. Quantitative Descriptive Analysis

This analysis was used to answer the formulation of problem regarding building quality and socio-culture and the second formulation of problem regarding accessibility. The quantitative analysis was done in the form of field data tabulation from interview result.

3. Spatial Analysis

Spatial analysis in this research used Citra map taken from Google Earth to map of housing land, area potency, and accessibility and infrastructure condition. This method aims to show the real existing condition in the development area on the first and second formulations of problem in this research. In addition, spatial analysis used in this research is in the form of photo mapping that uses land use map.

4. Comparative Analysis

The analysis was used to answer the second formulation of problem regarding condition of supporting facility and infrastructure in the ecotourism development.

\section{General Overview}

Geographically, Pannikiang Island located between 04'19'45.21-04'22'19.93 South Latitude and $119^{\circ} 34^{\prime} 32.45-119^{\circ} 36^{\prime} 46.22$ East Longitude. From the appearance of Citra Brand 123, it can be seen the length of the island is 2899 meters and the width is 344 meters with an area of $94.5 \mathrm{Ha}$ (Tourism Potential Data of Barru Regency, 2016).

Pannikiang Island or also called Panning Island coming from Bugis language that means bat island where there are many bats in the island. The southern is divided into 2 neighborhood groups (RT) with 103 inhabitants. 


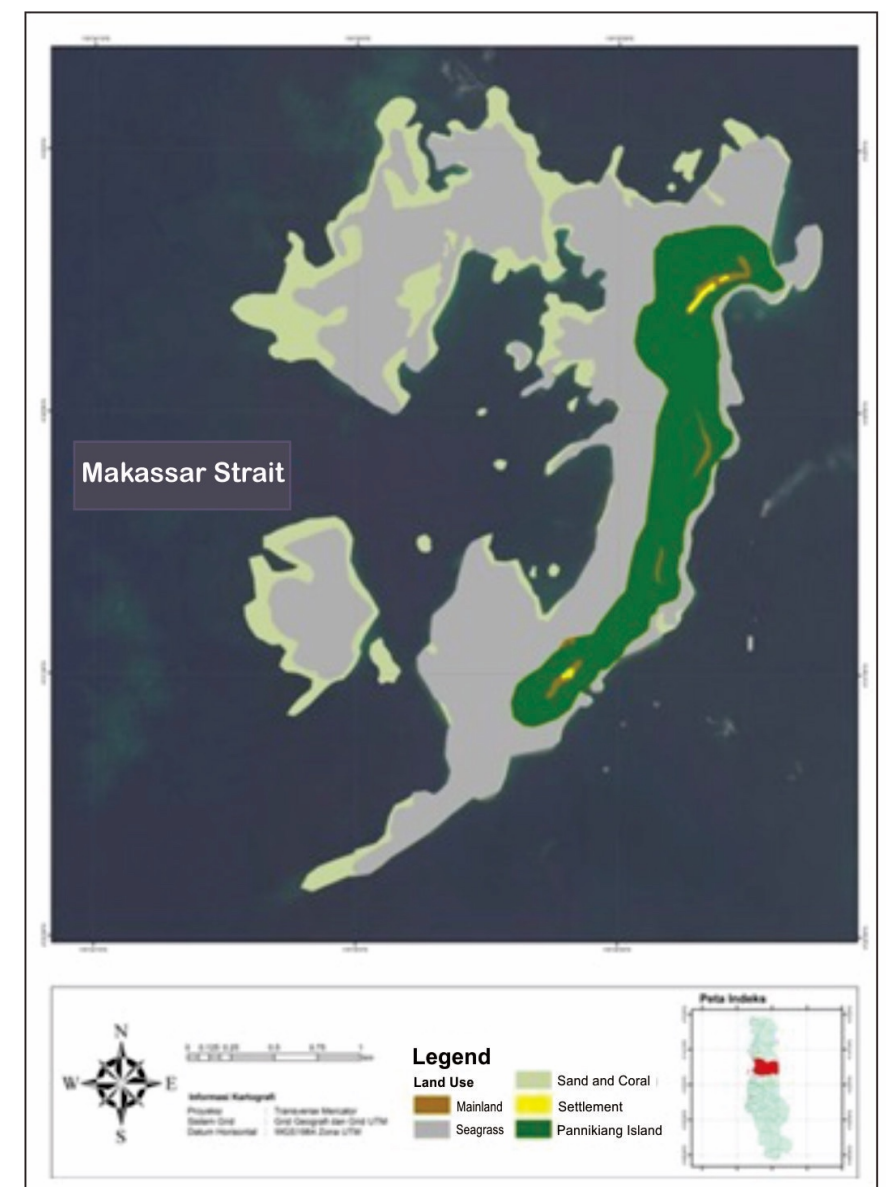

Figure 2. Maping of Pannikiang Island

\section{RESULTS AND DISCUSSIONS}

\section{Housing Land and Potential Area Analyses}

Pannikiang Island consists of two parts which are first neighborhood group (RT 1) and second neighborhood group (RT 2). There are 28 units in RT 1 and 6 units in RT 2. In general, housing characteristics in Pannikiang Island is stilt house. Many stilt houses in Pannikiang Island are not fully inhabited by the indigenous. Many fishermen from Mandar stop by and even settle in the island. Housing Land which will be analyzed consisting of several indicators such as building characteristic, building orientation, distance between buildings, and distance between building and sea. 


\section{Building Characteristic}

Table 1.Building Characteristic

\begin{tabular}{ccccc}
\hline & \multicolumn{2}{c}{ RT 1 } & \multicolumn{3}{c}{ RT 2 } \\
\cline { 2 - 5 } Building & Total & Total \\
Characteristic & Units & \% & Units & \% \\
\hline Stilt House & 26 & 96,1 & 5 & 83,3 \\
Semi Stilt House & 1 & 3,9 & - & - \\
Non-Stilt House & - & - & 2 & 16,7 \\
Total & 28 & 100 & 6 & 100 \\
\hline Source: Survey Results and Researcher's Analysis, 2017
\end{tabular}

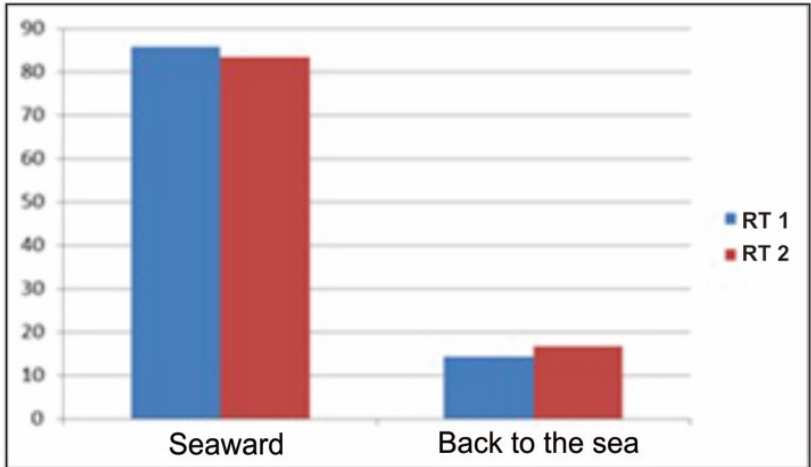

Figure 3.Graph of Building Characteristic Source: Survey Results and Researcher's Analysis, 2017

Based on the analysis results of existing housing characteristics in Pannikiang Island, the overall characteristic of the dominant residential building is stilt house both on RT 1 and RT 2. In ecotourism development, the stilt house condition must be in accordance with ecotourism concept which is as the potential of eco-friendly accommodation. It is because the stilt house has a good lighting and circulation. The openings found in the stilt house can be utilized to enjoy beautiful views of sea and mangrove forest so it is not necessary to use air conditioner.

\section{Building Orientation}

Table 2. Building Orientation

\begin{tabular}{lllll}
\hline Building & $\begin{array}{l}\text { RT 1 } \\
\text { Total }\end{array}$ & \multicolumn{3}{c}{ RT 2 } \\
Orientation & Units & $\mathbf{\%}$ & Total & \\
\hline Facing the Sea & 24 & 85,7 & 5 & \% \\
Behind the Sea & 4 & 14,3 & 1 & 16,3 \\
Total & 28 & 100 & 6 & 100 \\
\hline \multicolumn{4}{c}{ Source: Survey Results and Researcher's Analysis, 2017 }
\end{tabular}




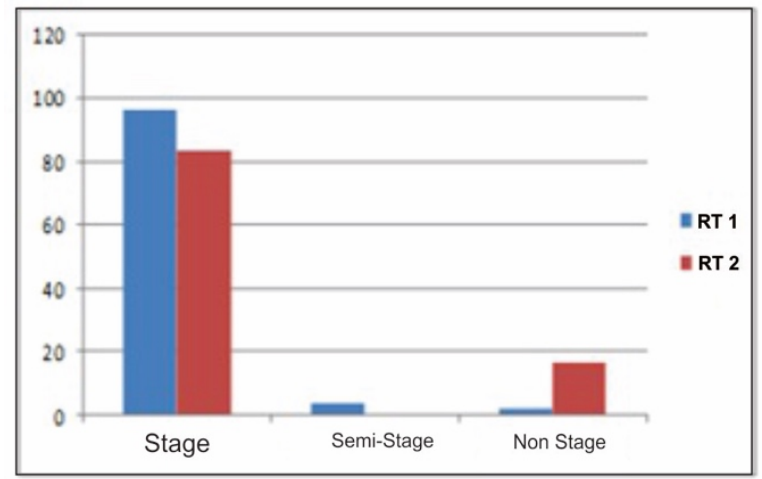

Figure 4. The Graph of Building Orientation

Source: Survey Results and Researcher's Analysis, 2017

The residential building orientation mostly facing the sea will support ecotourism principle, in this case eco-friendly because the household waste is not directly discharged into the sea. This condition is certainly different from the houses with its back to the sea that could potentially do environmental pollution through household waste disposal directly to the back of the house.

Based on the Regulation of the Minister of Culture and Tourism Num on General Guidelines for Tourism Development on Small Islands, the tourism supporting buildings should face the sea and not be blocked by other buildings. It is in accordance with the existing condition of Pannikiang Island housing that will be developed into a community-based economic application have a direct impact on the improvement of local community's economy.

\section{Distance between Buildings}

The distance between one building to another in Pannikiang Island housing tends to vary from $3 \mathrm{~m}$ to $4 \mathrm{~m}$. In order to reduce impact of environmental damage and disruption the existence of mangrove forest in Pannikiang Island and to support ecotourism development, the housing can be developed into accommodation facilities. Building density conditions are categorized as not dense but the distance between buildings need to be set 6 meters away with the consideration of: standard minimum distance is $1 / 2$ of house height and privacy between houses as well as a strong sense of togetherness. The development of new accommodation facilities will certainly require feared land that will disrupt the existing ecosystem. So, the housing development as a means of accommodation is the right thing to do.

\section{Coastal Demarcation Line}

Based on Presidential Regulation of the Republic of Indonesia No. 51 of 2016 on coastal demarcation line, coastal demarcation is land along coastal edge that is proportional to the coast shape and physical condition, at least 100 (one hundred) meters from the highest tide point to land. At the research site, the housing is included within a radius of coastal demarcation. However, the availability of embankments can minimize the highest tide which is $5 \mathrm{~m}$ and the tide cannot reach 
the existing housing. In addition, the existence of mangrove vegetation protects the coastal areas, especially during the season where the wind and waves are large, but the waves on Pannikiang Island remain calm.

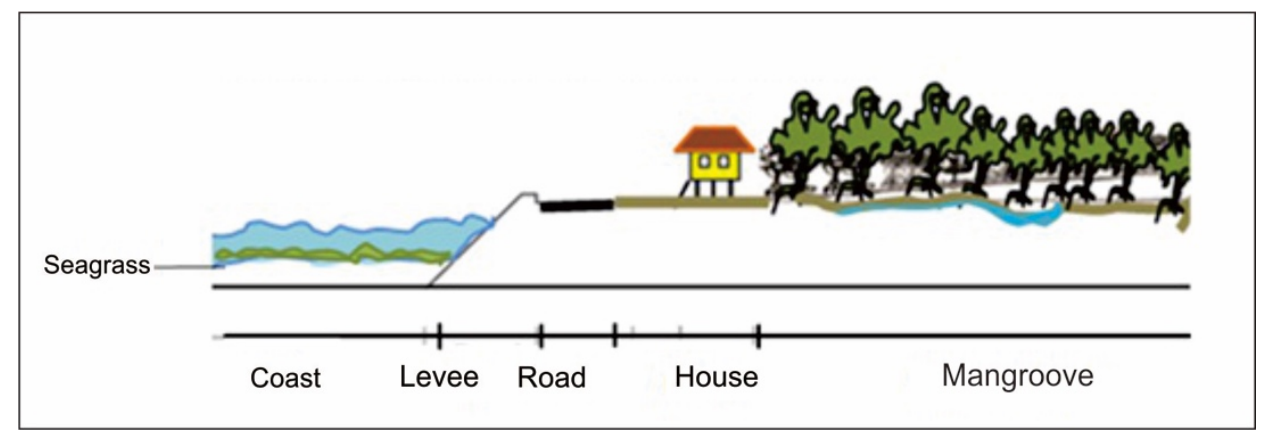

Figure 5. An illustration of area pieces Source: Survey Result, 2017

\section{Natural Potency}

One of the main potential or main tourist attraction on Pannikiang Island is the view of diverse mangrove vegetation. The mangrove covered area on Pannikiang Island reaches 86.31 hectares covering $91 \%$ of the island's land. In addition to the potential of mangrove diversity, there are coral reef ecosystems with an area of 331.63 Ha in Pannikiang Island (Tourism Potential Data of Barru Regency, 2016). The mangroves diversity and coral reefs owned by Pannikiang island has its own uniqueness that can be developed into a tourist area, especially for ecotourism being able to be the trigger of local community economy and support the nature conservation.

\section{Flora and Fauna}

Mangrove is a plant that lives on the coast. Mangroves can grow in areas that $30 \%$ submerged in water. Vegetation types that compose mangrove ecosystems in Pannikiang Island are 30 species consist of 17 species of original mangroves and 13 species of hybrid mangrove. The mangrove ecosystem in the island has certain characteristics compared to other mangrove ecosystems in South Sulawesi which is a place for thousands of bats to nest. Besides bats, Pannikiang also has 20 bird species from 16 families (Fatah,2013).

On Pannikiang Island, there are also mangrove crab and mangrove oyster. The existence of mangroves become a source of food and habitat for mangrove crabs. In addition, the existing seagrass ecosystem in Pannikiang Island allows the existence of dugong (Duyung) because the seagrass is the main source of food for the dugong. 


\section{Socio-Economic Culture}

In general, the livelihood of Pannikiang Island residents is fishermen with average income approximately from Rp. 500.000 to Rp. 1.000.000,-/ month depending on the fish acquired. Based on the results of the primary data conducted through the interview, education level of Pannikiang Island residents is generally low as shown below:

Table 3. Education Level Analysis of Pannikiang Island Residents

\begin{tabular}{ccc}
\hline Education Level & $\mathbf{n}$ & $\mathbf{\%}$ \\
\hline No School & 11 & 36,6 \\
Elementary & 5 & 16,6 \\
Junior High & 7 & 23,4 \\
Senior High & 7 & 23,4 \\
\hline Total & 30 & 100 \\
\hline
\end{tabular}

Source: Survey Result, 2017

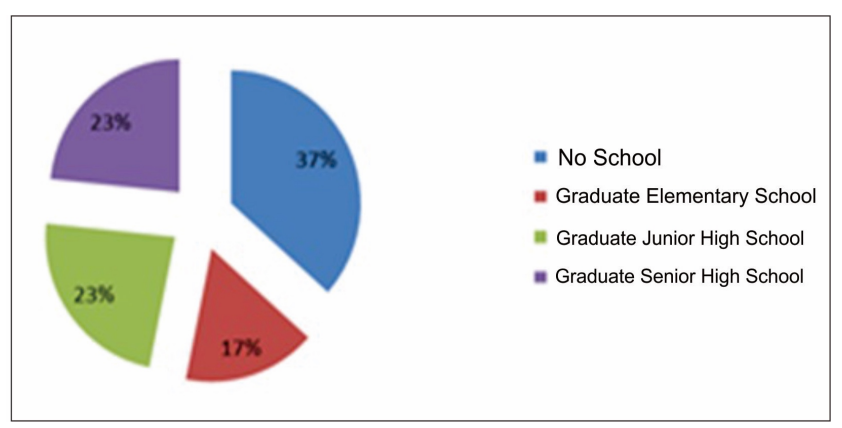

Figure 6. Education Level Diagram of Pannikiang Island Residents Source: Survey Results and Researcher's Analysis, 2017. 


\section{Accessibility and Supporting Infrastructure Analysis}

\section{a. Accessibility}

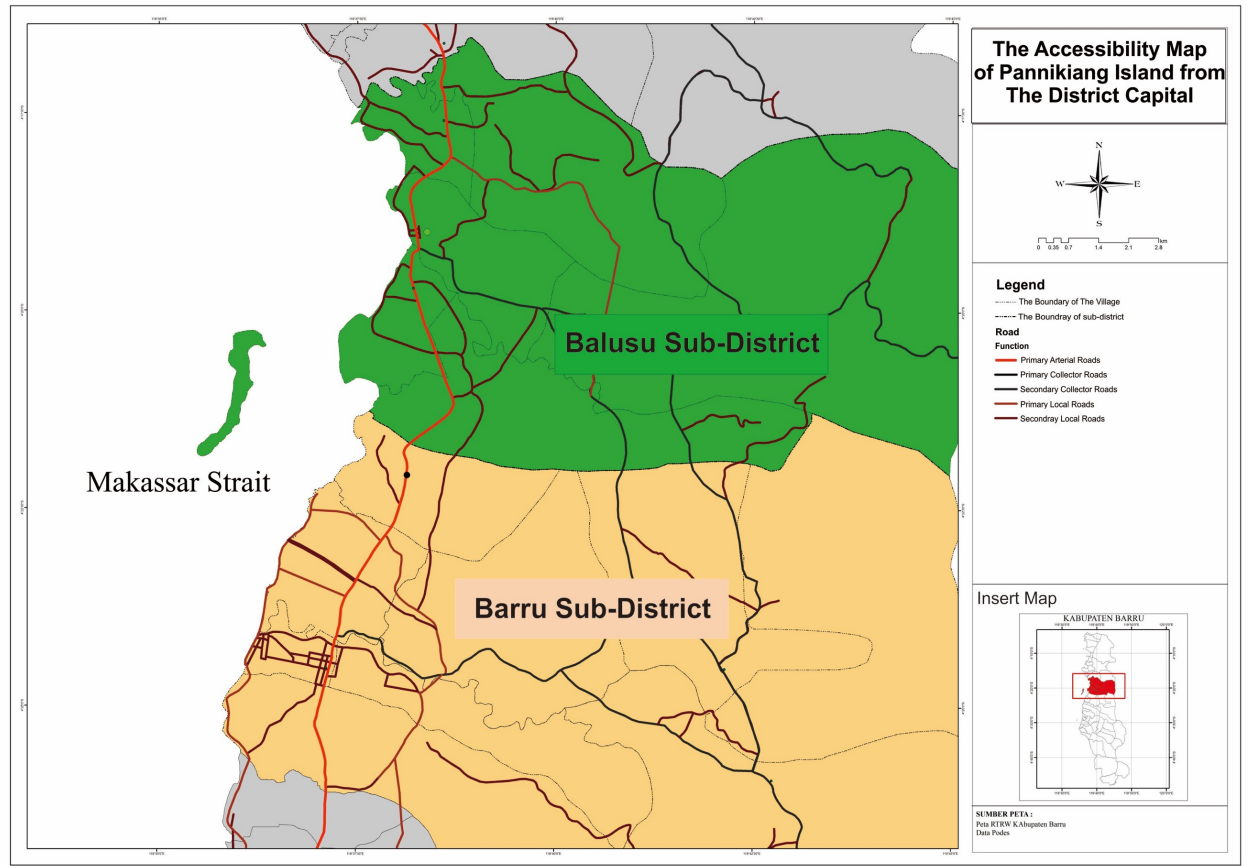

Figure 7. Accessibility Map to Pannikiang Island Source: Survey Results and Researcher's Analysis, 2017.

Table 4. Access Analysis to Pannikiang Island

\begin{tabular}{|c|c|c|c|c|c|}
\hline No & $\begin{array}{l}\text { Accessible } \\
\text { Route }\end{array}$ & $\begin{array}{c}\text { Distance } \\
(\mathrm{km})\end{array}$ & $\begin{array}{c}\text { Time } \\
\text { (minut } \\
\text { es) }\end{array}$ & Cost & $\begin{array}{l}\text { Signs Direc- } \\
\text { ntions }\end{array}$ \\
\hline 1 & $\begin{array}{c}\text { Ujung Batu } \\
\text { Coast }\end{array}$ & 7,8 & $40-45$ & Rp. 200.00-Rp. 300.000 & Not Avail -able \\
\hline 2 & $\begin{array}{l}\text { SumpangBin } \\
\text { angae Coast }\end{array}$ & 6,5 & $35-40$ & Rp. 200.00-Rp. 300.000 & Not Avail- able \\
\hline 3 & $\begin{array}{l}\text { Ujungnge } \\
\text { Coast }\end{array}$ & 4,8 & $25-30$ & Rp. 200.00-Rp. 300.000 & Not Avail -able \\
\hline
\end{tabular}

Source: Survey Results and Researcher's Analysis, 2017

\section{Supporting Facility and Infrastructure and Development Directives}

Based on the observations, there is one unit of rental house as an accommodation. However, the house condition is less maintained, so most tourists tend not to stay on the island. Based on the consideration, it is necessary to fulfill the accommodation to support the tourists needs in the form of a homestay in order to develop Pannikiang Island as an ecotourism area. 
Trade facilities and services found in Pannikiang Island are only tour supporting facilities that are several gazebo units along the mangrove tracks, toilets, stalls, and mosque. Other facilities is not yet available, such as food stalls and gift shops. Based on the questionnaire results, $94 \%$ of housewives expressed their willingness to participate in making food products, marine handicrafts and mangrove products. It is necessary to provide other supporting facilities such as information rooms and public toilets that are more representative in order to support the development of Pannikiang island as an ecotourism area.

Infrastructure condition. The existing road network on Pannikiang Island is made of soil with a width of $1 \mathrm{~m}$. The main water source on Pannikiang island is not from artesian wells and PDAMs (Local Water Company). Type of clean water source used by the residents of Pannikiang Island consist of water gallons and rainwater or artesian well obtained from Madello or Siawung villages. The power source of Pannikiang island residents is diesel power (generator). For the road network development, it must be made in the form of paving streets with minimum width of $1.8 \mathrm{~m}$ to make tourists being more comfortable while the road on the mangrove track area in the form of footbridge with minimum width of $1.8 \mathrm{~m}$ made of a good quality and waterproof wood material. The clean water source is developed by using an artesian well combined with a water purification system. The power source directive is by using solar or wind power that is more economical and eco-friendly.

There are four docks at the research site. However, only two docks are used by the residents in everyday. Those docks are used for tourists and fishermen boats. The existence of docks on Pannikiang Island has a potential to be developed for boating tours. 


\section{Development Directives and Concepts}

\section{a. Development Directives of Ecotourism Activity}

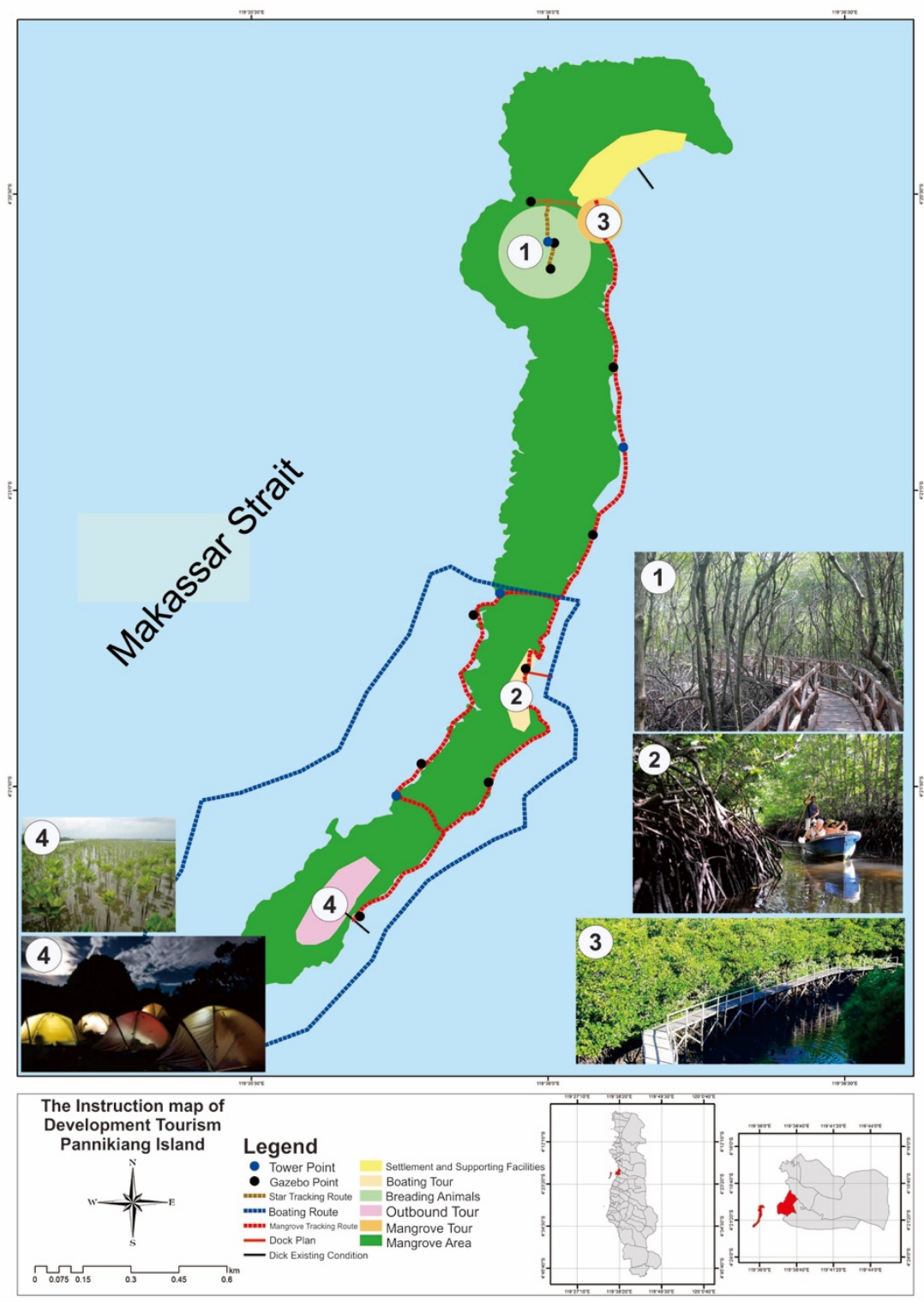

Figure 8. .Mapping of Tourism Activity Directives on Pannikiang Island 


\section{b. Accessibility of Development Directives}
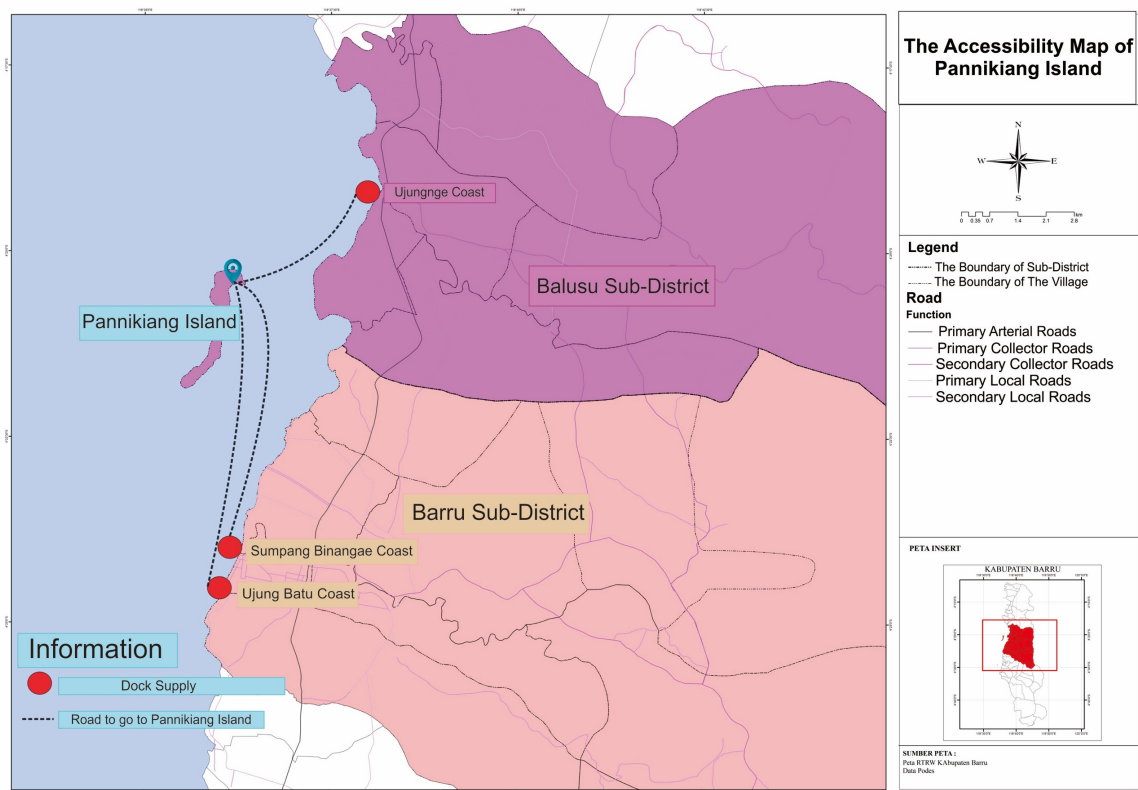

Figure 9. Map of Docks Directives to Pannikiang Island

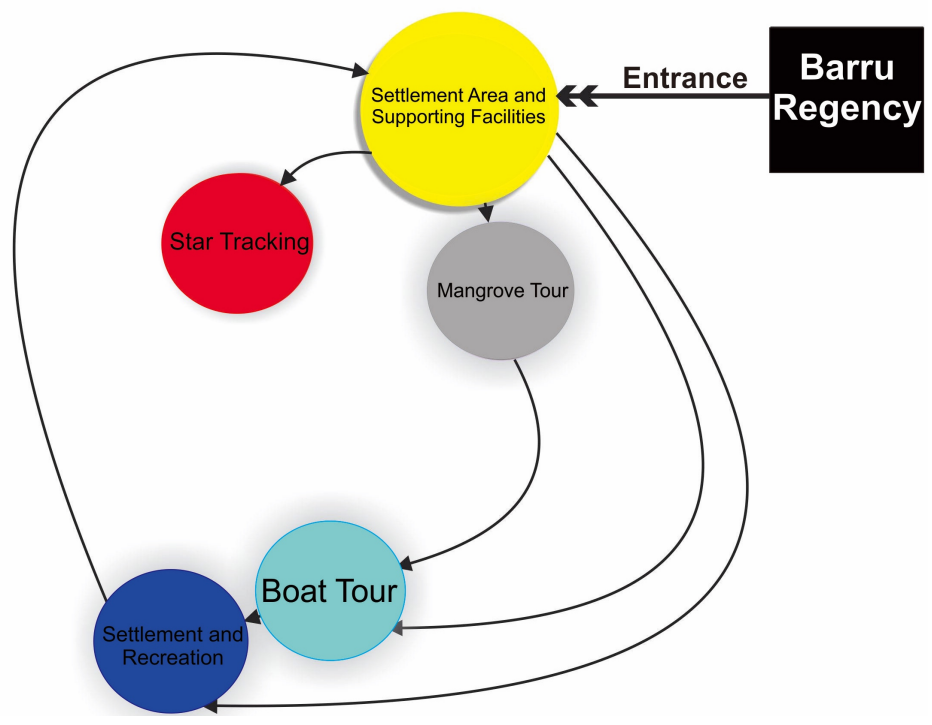

Figure 10.Circulation Flow of Tourists from Residential Areas and Supporting Infrastructure. 

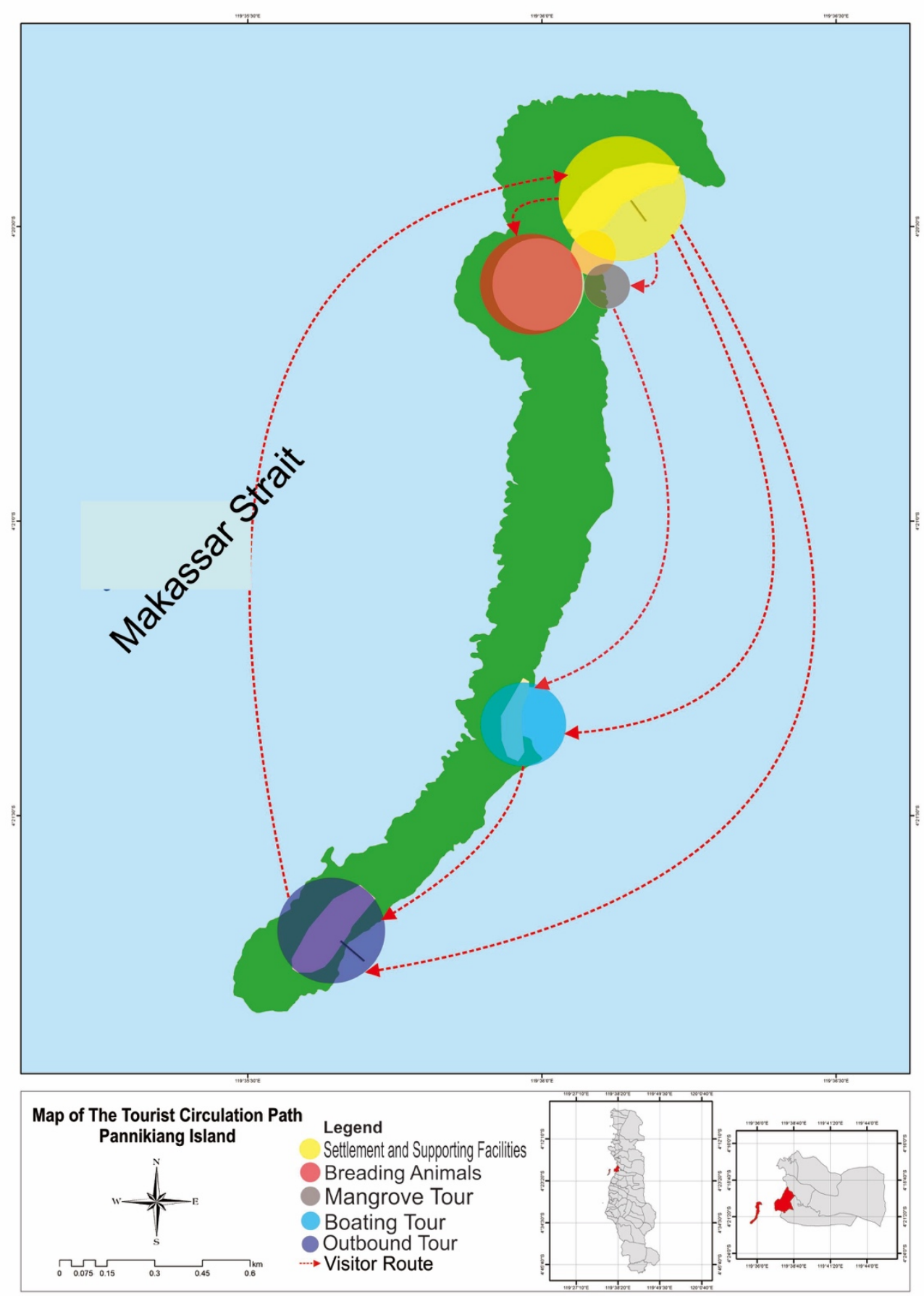

Figure 11.Map of Tourists Flow on Pannikiang Island Source : Researcher's Analysis Results, 2017 


\section{c. Development Directives of Supporting Facility and Infrastructure}

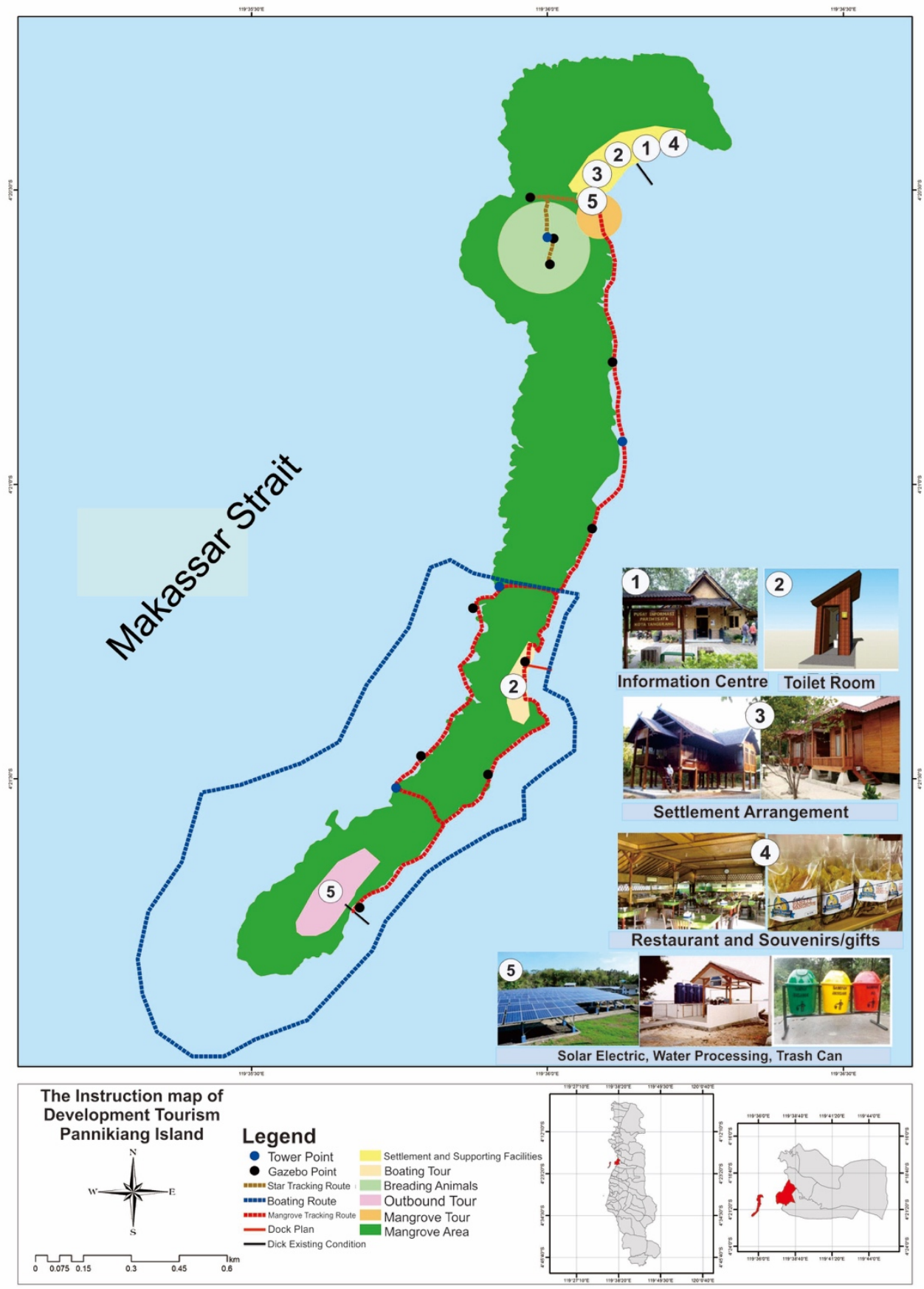

Figure 12. Mapping Map of Ecotourism Supporting Facility and Infratructure Directives on Pannikiang Island 


\section{d. Development Directives of Community-based Ecotourism}

1. Local fishermen community forms an organization or institution for ecotourism activities management with funding support from local government and private party which start from training and mentoring (community-based participation value).

2. Principle of local ownership (management and ownership by the community) is applied to ecotourism facilities and infrastructures (the accommodation of boat rental, restaurant, and mangrove tourism).

3. Homestay is an option for accommodation and creativity development of local community in making souvenirs by processing marine products and mangroves (economic and social values).

4. Tour guide from the local community who knows the ins and outs of the location and has been through training.

5. Pioneering (planning, development), management, and maintenance of tourism objects become the responsibility of local community (as an additional income that supports livelihood as fisherman especially if he does not go to the sea).

\section{CONCLUSIONS}

There are several conclusions obtained from the research:

1. The residential land and potential areas in Pannikiang Island have potential to develop ecotourism. The housing can be used as an accommodation whilst the natural panorama and diversity of flora and fauna natural potentially developed as a sustainable ecotourism.

2. There are three accesses that can be used to go to Pannikiang Island which are through Ujung Batu, Sumpang Binangae, and Ujungnge coasts. There is also a dock but no signposts in those three accesses. The condition of supporting infrastucture in ecoutourism development in Pannikiang island is not yet available. There is a low-quality rental house, a mosque, and a toilet. Other supporting facilities are not yet availability such as tourist service, trade service, and supporting ecotourism activity facilities that will be developed.

3. Development directives of ecotourism-based housing in Pannikiang island are as follows: A directive in which housing is developed into homestay, community involvement in managing ecotourism activity, accessibility development directives are improvement of dock and its signposts, supporting infrasturcture development directive is community-based ecotourism.

\section{REFERENCES}

Hadinoto, Kusudianto. (1996), Perencanaan Pengembangan Destinasi Pariwisata. Jakarta. UI Press.

Kabupaten Barru Dalam Angka(2016).

Kecamatan Balusu Dalam angka (2016). 
Sinulingga, B.D. (2005), Pembangunan Kota. Tinjauan Regional dan Lokal. Jakarta. Pustaka Sinar Harapan.

Sugiyono. 2012. Memahami Penelitian Kualitatif. Bandung. Alfabeta.

Tuwo, Ambo. (2011),Pengelolaan Ekowisata Pesisir dan Laut. Surabaya. Brilian Internasional.

Yoeti, Oka. (2002), Perencanaan \& Pengembangan Pariwisata. Jakarta: PT. Pradaya Paramita.

Fatah, Ambeng, Priosambodo (2013), Keanekaragaman Jenis Burung di Pulau Pannikiang Kabupaten Barru Sulawesi Selatan. Jurnal. Makassar. Universitas Hasanuddin.

Nugrahanti, Imroatul dan Navastara, Ardy. (2012), Pengembangan Permukiman Nelayan Berbasis Ekowisata di Pantai Timur Surabaya. Jurnal. Surabaya. InstitutTeknologi Sepuluh November.

Nursalam, Malaeika, Setyo.(2016), Pemanfaatan Sungai Tallo Sebagai Potensi Waterway yang berbasis Ekowisata di Kota Makassar. Jurnal. Makassar. Universitas Hasanuddin.

Purnamasari. (2015), Penataan Permukiman Produktif Berbasis Industri Rumput Laut Studi Kasus Desa Lamalaka Kabupaten Bantaeng. Skripsi. Makassar. Universitas Hasanudin.

Suwardi, Tambaru, Ambeng, Priosambodo.(2013), Keanekaragaman Jenis Mangrove di Pulau Pannikiang Kabupaten Barru Sulawesi Selatan. Jurnal. Makassar. Universitas Hasanuddin.

Waluya, Bagjadan Jamil, Rima. (2016), Pengaruh Elemen Ekowisata Terhadap Keputusan Berkunjung Wisatawan ke Taman Hutan Raya Ir. H. Djuanda. Jurnal. Bandung. Universitas Pendidikan Indonesia.

Wardani, Ayu Wardani. (2014), Penataan Kampung Nelayan Desa BendarBajomulyo Kecamatan Juwana Kabupaten Pati. Jurnal. Semarang. Universitas Diponegoro.

Direktorat Jenderal Cipta Karya Departemen Pekerjaan Umum Nomor 43/KPTS/CK/1999 tentang Petunjuk Teknis Pembangunan Perumahan Nelayan.

Kamus Tata RuangTahun (1997).

Pedoman Kriteria Teknis Kawasan Budidaya Peraturan Menteri Pekerjaan Umum Nomor 41/PRT/M/2007.

Peraturan Menteri Dalam Negeri Nomor 33 Tahun 2009 tentang Pedoman Pengembangan Ekowisata di Daerah.

Peraturan Menteri Kebudayaan dan Pariwisata Nomer: KM.67/ UM.001/ MKP/ 2004 tentang Pedoman Umum Pengembangan Pariwisata di Pulau-pulau Kecil.

Peraturan Menteri Negara Perumahan Rakyat Republik Indonesia Nomor 15/Permen/M/2006 tentang Petunjuk Pelaksanaan Penyelenggaraan Pengembangan Kawasan Nelayan.

SNI 03-1733-2004 Tata Cara Perencanaan Linkungan Perumahan di Perkotaan. Undang-undang Nomor 01 Tahun 2011 tentang Perumahan dan Permukiman.

Undang-undang Nomor 26 Tahun 2007 tentang Penataan Ruang.

Undang-undang Nomor 10 Tahun 2009 tentang Kepariwisataan. 